\title{
Sexual castes of Trachymyrmex fuscus (Formicidae: Attini) performing worker tasks
}

\section{Castas sexuadas de Trachymyrmex fuscus (Formicidae: Attini) executando tarefas de operárias}

\author{
Márcio da Silva Araújo ${ }^{I^{*}}$ João Paulo Ribeiro Oliveira ${ }^{\mathrm{I}}$ Danival José de Souza \\ Marco Antônio Oliveira ${ }^{I I I}$ Flávio Gonçalves de Jesus ${ }^{\mathrm{IV}}$
}

\section{ABSTRACT}

The main of this research was to report an atypical foraging behavior in a colony of Trachymyrmex fuscus, situated in "Cerrado" (savanna ecoregion of Goiás, Brazil). The colony foraging activity was performed only by sexual caste. Comparison of the foraging rhythm of this colony with another of the same specie where foraging was performed only by worker caste, showed that working time hours were very similar. After observations on the foraging behavior, both colonies were excavated in order to characterize them (nest size, population composition and estimating of the symbiotic fungus volume). Besides the foraging activity performed only by sexual females, other important observations were highlighted in that colony: low number of workers, presence of worker larvae and pupae 45 and 43 respectively) and apparently normal growth of the symbiotic fungus. Our hypothesis is that sexual females were in charge of the entire colony maintenance. This could be a strategy of colony survival when the worker caste is reduced.

Key words: fungus-growing ant, foraging activity, division of labour, polymorphism.

\section{RESUMO}

Este trabalho objetivou registrar um comportamento atípico de forrageamento em uma colônia de Trachymyrmex fuscus, localizada em área de cerrado, em Ipameri, Goiás, Brasil. Nessa colônia, a atividade de forrageamento era executada somente por castas sexuadas. A comparação do ritmo diário de forrageamento dessa colonia com o de outra, da mesma espécie, em que tal atividade era executada por castas operárias, mostrou ritmos das jornadas de trabalho relativamente similares. Essas colonias foram escavadas para sua própria caracterização. Além da atividade forrageadora, executada somente por fêmeas, outras observações relevantes mereceram destaque na referida colônia: inexpressivo número de operárias (5), presença de larvas e pupas de operárias (45 e 43, respectivamente) e crescimento aparentemente normal de fungo simbionte. Nossa hipótese é a de que as fêmeas sexuadas faziam a manutenção de toda a colônia. Essa pode ser uma estratégia para a sobrevivência da colônia em um momento em que a casta operária encontra-se reduzida.

Palavras-chave: formiga cultivadora de fungo, ritmo de forrageamento, divisão de trabalho, polimorfismo.

Division of labor is key to the success of many social animals, most notably the social insects, as specialized individuals work more efficiently to accomplish tasks (HUGHES \& BOOMSMA, 2007). An important characteristic of labor division in insect societies is their flexibility, which enables colonies to respond to internal and external changes by adjusting the number of workers engaged in different colony tasks (ROBINSON, 1992). According to GORDON (1996), in ant colonies the division of labor is directly related to associations between the workers' body size, age and genetic propensity towards the type of task to be accomplished, the latter being likely responsible for temporal polyethism. Recently, FERGUSON-GOW et al. (2014) proposed that the complexity of tasks performed by workers and even queens is directly linked to the colony size.

The Attini foraging pattern has been extensively studied in the Neotropical region, and foraging activity being carried out by sexual castes

\footnotetext{
'Universidade Estadual de Goiás (UEG), Campus Ipameri, 75780-000, Ipameri, GO, Brasil. E-mail: marcio.araujo@ueg.br. *Corresponding author.

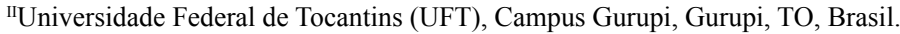

"IIniversidade Federal de Viçosa (UFV), Campus Florestal, Florestal, MG, Brasil.

${ }^{\text {IV }}$ Instituto Federal Goiano (IF Goiano), Campus Urutai, Urutai, GO, Brasil. 
has been rarely reported. One of such few reports on atypical behavior of Acromyrmex subterraneus subterraneus and Acromyrmex niger colonies under laboratory conditions was made, though not in detail, by DELLA LUCIA et al. (1993), in Minas Gerais state, Brazil. The authors pointed out that on rare occasions non-winged females carried out the activity. In fact, the colony workers were the ones that actually carried out the foraging.

Trachymyrmex is an inconspicuous genus of Attini, featuring monomorphic workers with tuberculate gaster. According to BRANDÃO et al. (2011), these genus species nourish their symbiotic fungus primarily with dead organic matter, feces and insect carcasses. However, since the species herein studied has been reported to injure Eucalyptus seedlings and sprouts in Brazil (ANJOS et al., 1998), it deserves special attention, especially when considering the application of granular ant bait pesticides to control it.

This study was designed to record the atypical foraging behavior of a Trachymyrmex fuscus colony in which sexual castes carried out foraging. The colonies were established on UEG Experimental Farm in Ipameri town, Goiás state,

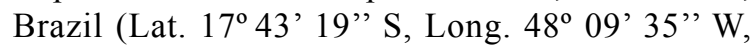
Alt. $773 \mathrm{~m})$. The atypical behavior was observed during three consecutive 24-hour working periods in November 2008 and compared to the daily foraging of a colony in which only sexual castes (workers) performed that activity. The studied colonies were located $5.0 \mathrm{~m}$ away from each other, and the daily foraging was measured based on the number of workers or sexual females transporting into the nest any kind of plant load visible by naked eye. Day and night the number of loadtransporting workers was recorded during 10 minutes as proposed by MACIEL et al. (1995).

After the foraging observation was completed, the colony nests were excavated using a mattock to gradually expose the channels and chambers and allow for characterization of the nests and collection of the material present in the chambers and channels (fungus and youth and adult colony members). As recommended by ARAÚJO et al. (2002), the chambers and channels were marked with talc for better visualization (Figure 1A).

The fact that such colonies have a small number of foraging workers and sexual individuals makes it difficult to visualize well-defined working periods, as observed by ARAÚJO et al. (2004). Even so, foraging peaks were recorded
(Figure 1B). The foraging time in both colonies was practically the same, with lower intensity being observed in the atypical colony. Overall, it was carried out from 02:00 to 09:00 PM and from 06:00 to 10:00 AM. The sexual castes presented foraging peaks mostly between 06:00 and 09:00 PM and between 07:00 and 08:00 AM.

Climatic conditions typical of November in the studied region (cloudy weather alternated with indirect sunlight in the colony) may have contributed to the fact that the ants performed foraging even in full sun, a behavior already reported on the species by ARAÚJO et al. (2002). Also observed by the same authors was that the plant material transported by workers was comprised of laid off, dried plant fragments and occasionally seedlings, as shown in figure $1 \mathrm{~A}$.

After the observation of the foraging activity was completed, the nests of both colonies studied were excavated for characterization, as shown in table 1 and figure 1A. The atypical colony had 466 individuals (five workers, 432 wingless females +29 winged, distributed into a fungal volume of about $0.7 \mathrm{~L}$ ), whereas the typical colony presented 728 individuals (719 workers and nine wingless females, distributed into a fungal volume of about 1.1L).

As in this study, NEHRING et al. (2012) reported on non-inseminated wingless virgins of Acromyrmex echinatior and Acromyrmex octospinosus behaving as workers, that is, carrying out activities typical of the worker caste. According to these authors, this behavior in the Acromyrmex genus may be explained by two reasons: (1) cloistered foundation, which means that the reproducing caste has not lost its foraging capacity since it has performed such role during the colony establishment, and (2) the almost exclusive habit of feeding from fungi, which implies that workers cannot feed from the sexual caste as is the case with other ant species. This would prevent recovery of the energy spent on production of this caste by simple ingestion.

The determination of sexual worker larvae and pupae (45 and 43, respectively) in the fungal mass of the atypical colony, as well as the clear incorporation of fresh plant substrate into the fungal mass, and inexpressive number of workers (5), also indicated that these sexual castes performed relevant activities within the colony, such as caring for fungi and young individuals, thus ensuring survival until the potential reestablishment of the non-sexual worker population. 


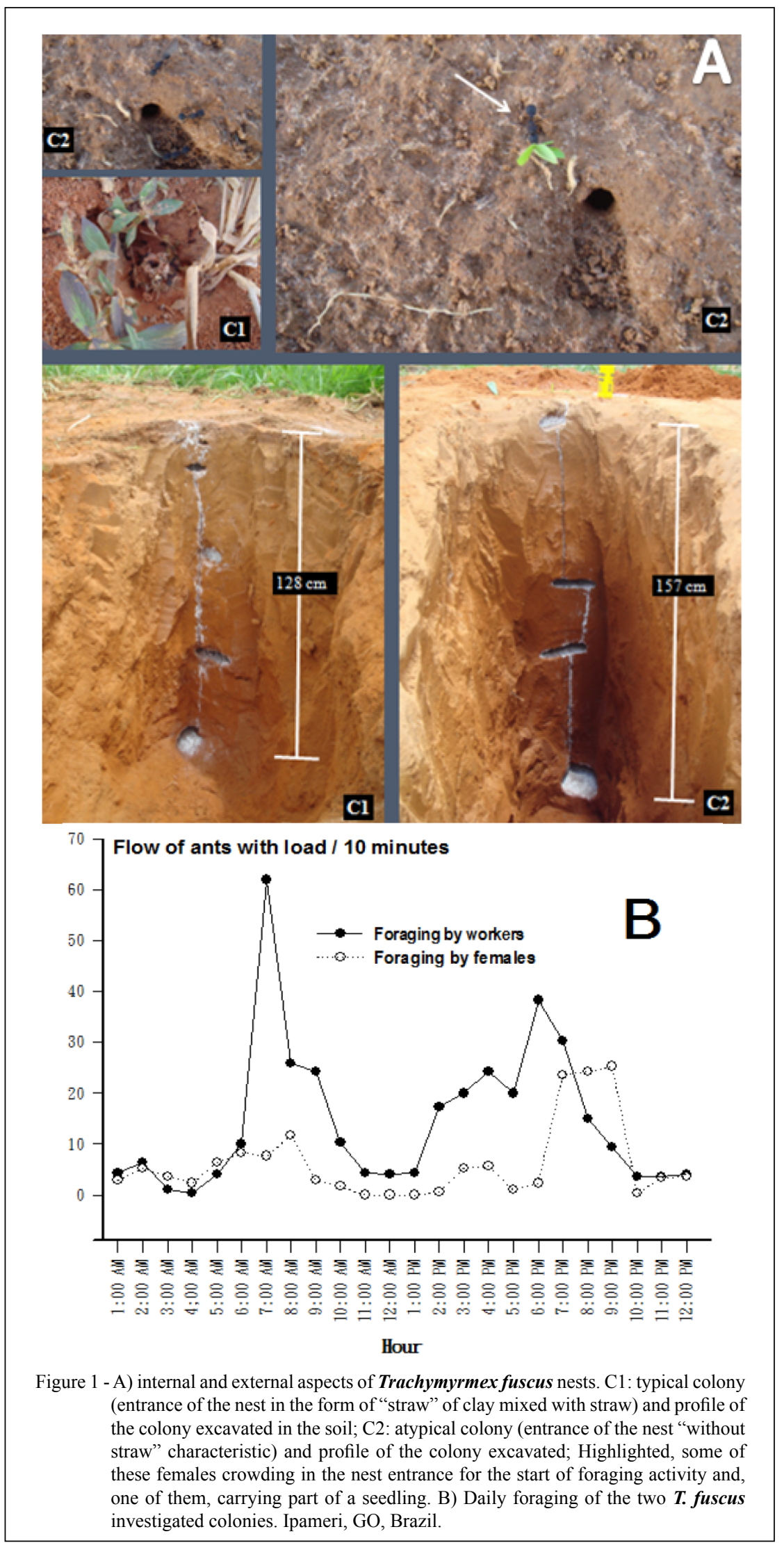

Ciência Rural, v.46, n.2, fev, 2016. 
Table 1 - Population composition and fungus volume of Trachymyrmex fuscus nests, after excavation. Ipameri, GO, Brazil.

\begin{tabular}{lcccc}
\hline \multirow{2}{*}{ Nests } & Fungus volume (L) & \multicolumn{2}{c}{---Number of individuals--- } \\
& & Larvaes & Pupaes & Adults \\
\hline Typical & 1.114 & 173 & 129 & $728^{*}$ \\
Atypical & 0.736 & 45 & 43 & $466^{* *}$ \\
\hline
\end{tabular}

*(719 workers +9 wingless females); ${ }^{* *}$ (432 wingless +29 winged +5 workers).

\section{ACKNOWLEDGEMENTS}

To agronomists Lucas P. Nunes and Robson F. Greguer for the assistance during fieldwork. The Coordination improvement of senior staff at AUXPE 2370/2014 project.

\section{REFERENCES}

ANJOS, N. et al. Guia prático sobre formigas cortadeiras em reflorestamentos. Ponte Nova: Graff Cor, 1998. 97p.

ARAÚJO, M.S. et al. Caracterização de ninhos e atividade forrageadora de Trachymyrmex fuscus Emery (Hymenoptera: Formicidae) em plantio de eucalipto. Revista Brasileira de Zoologia, v.19, p.419-427, 2002. Available from: <http:// www.scielo.br/pdf/rbzool/v19n2/v19n2a08.pdf>. Accessed: aug 01, 2015.

ARAÚJO, M.S. et al. Impacto da queima da palhada da canade-açúcar no ritmo de forrageamento de Atta bisphaerica Forel (Hymenoptera: Formicidae). Revista Brasileira de Zoologia, v.21, p.33-38, 2004. Available from: <http://www.scielo.br/pdf/ rbzool/v21n1/19706.pdf>. Accessed: Aug 01, 2015.
BRANDÃO, C.R.F. et al. Taxonomia e filogenia das formigascortadeiras. In: DELLA LUCIA, T.M.C. Formigas-cortadeiras: da biologia ao manejo. Viçosa: UFV, 2011. p. 27-48.

DELLA LUCIA, T.M.C. et al. Castas de formigas cortadeiras. In: DELLA LUCIA, T.M.C. As formigas cortadeiras. Viçosa: Folha de Viçosa, 1993. p.43-53.

GORDON, D.M. The organization of work in social insect colonies. Nature, v.380, p.121-124, 1996.

FERGUSON-GOW, H. et al. Colony size predicts division of labour in attine ants. Proceeding of the Royal Society, v.281, p.1-9, 2014. Available from: <http://dx.doi.org/10.1098/ rspb.2014.1411>. Accessed: aug 01, 2015. doi: 10.1098/ rspb.2014.1411.

HUGHES, W.O.H.; BOOMSMA, J.J. Genetic polymorphism in leaf-cutting ants is phenotypically plastic. Proceeding of the Royal Society, v.274, p.1626-1630, 2007. Available from: <http:// rspb.royalsocietypublishing.org/content/royprsb/274/1618/1625. full.pdf>. Accessed: aug 01, 2015. doi: 10.1098/rspb.2007.0347.

MACIEL, M.A.F. et al. Ritmo diário de atividade forrageadora da formiga cortadeira Acromyrmex subterraneus subterraneus Forel. Anais da Sociedade Entomológica do Brasil, v.24, p.371-374, 1995.

NEHRING, V. et al. Wingless virgin queens assume helper roles in Acromyrmex leaf-cutting ants. Current Biology, v.22, p.671-673, 2012. Available from: <http://ac.els-cdn.com/ S0960982212007142/1-s2.0-S0960982212007142-main.pdf? tid=aeaf060e-385a-11e5-b337-00000aacb362\&acdnat $=1438439$ 963_4feaa49b577247b8c4a9716e8573935f>. Accessed: aug 01. 2015. doi: 10.1016/j.cub.2012.06.038.

ROBINSON, G.E. Regulation of division of labor in insect societies. Annual Review of Entomology, v.37, p.637-665, 1992. Available from: <http://www.annualreviews.org/doi/abs/10.1146/ annurev.en.37.010192.003225>. Accessed: aug 01, 2015. doi: 10.1146/annurev.en.37.010192.003225. 